\title{
Analysis of the $5^{\prime}$-upstream region of mouse $\mathrm{P} / \mathrm{Q}$-type $\mathrm{Ca}^{2+}$ channel $\alpha_{1 \mathrm{~A}}$ subunit gene for expression in pancreatic islet $\beta$ cells using transgenic mice and HIT-T15 cells
}

\section{E Takahashi, N Miyamoto and T Nagasu}

\author{
Laboratory of Seeds Finding Technology, Eisai Co. Ltd, 5-1-3, Tokodai, Tsukuba, Ibaraki, 300-2635, \\ Japan
}

(Requests for offprints should be addressed to E Takahashi; Email: e2-takahashi@hhc.eisai.co.jp)

\begin{abstract}
The $\omega$-agatoxin-IVA-sensitive $\mathrm{P} / \mathrm{Q}$-type $\mathrm{Ca}^{2+}$ channel plays a role in insulin release from the pancreatic islets of $\beta$ cells. To dissect the molecular mechanisms underlying $\beta$ cell expression of the $\mathrm{P} / \mathrm{Q}$-type channel, we characterized the $5^{\prime}$-upstream region of the mouse $\alpha_{1 \mathrm{~A}}$ subunit gene using transgenic mice and HIT insulinoma cells. The E. coli lac Z reporter gene was expressed in pancreatic acini and islets in transgenic mice carrying the $6.3 \mathrm{~kb}$ or $3.0 \mathrm{~kb}$ of the 5 -upstream region, although those with $1.5 \mathrm{~kb}$ or $0.5 \mathrm{~kb}$ of the $5^{\prime}$-upstream region failed to show reporter expression on histological examination. As the expression of $\alpha_{1 \mathrm{~A}}$ subunit gene could not be detected in acini using RT-PCR analysis, the reporter expression in acini might have been ectopic expression. When linked to the placental alkaline phosphatase reporter gene to examine promoter
\end{abstract}

activity for $\beta$ cell expression, the $6.3 \mathrm{~kb}$ and $3.0 \mathrm{~kb}$ fragment of the $5^{\prime}$-upstream region, but not the smaller $1.5 \mathrm{~kb}$ fragment, were able to drive reporter gene expression in HIT cells. The sequence between 3.0 and $1.5 \mathrm{~kb}$ upstream of the start codon enhanced thymidine kinase promoter activity in HIT cells, but not in fibroblast NIH3T3 cells. These results suggested that the $\beta$ cell-specific elements of the $\alpha_{1 \mathrm{~A}}$ subunit gene are likely to be located in the distal upstream region $(-3021$ to -1563 ) of the $5^{\prime}$-upstream sequence and that the $6.3 \mathrm{~kb}$ fragment of the $5^{\prime}$-upstream region alone might be a lack of a negative cis-regulatory element(s) to suppress the $\alpha_{1 \mathrm{~A}}$ subunit gene expression in acini.

Fournal of Molecular Endocrinology (2000) 24, 225-232

\section{INTRODUCTION}

Glucose augments insulin release from the pancreatic islet $\beta$ cells by altering the ATP/ADP ratio (Ashcroft et al. 1984, Newgard \& McGarry 1995). An increase in ATP relative to ADP inhibits ATP-sensitive $\mathrm{K}^{+}\left(\mathrm{K}_{\mathrm{ATP}}\right)$ channel activity and gives rise to membrane depolarization (Longo et al. 1991, Larsson et al. 1996). ATP-dependent depolarization increases $\mathrm{Ca}^{2+}$ influx through voltageactivated $\mathrm{Ca}^{2+}$ channels and evokes insulin secretion (Larsson et al. 1996). Removal of extracellular $\mathrm{Ca}^{2+}$ abolishes glucose-stimulated insulin secretion (Curry et al. 1968, Hales \& Milner 1968, Devis et al. 1975, Boyd 1992). This implies that the $\mathrm{Ca}^{2+}$ influx through voltage-activated $\mathrm{Ca}^{2+}$ channels is an important process for insulin release.

Several types of voltage-activated $\mathrm{Ca}^{2+}$ channels (L, P, Q, N and R) have been identified based on their pharmacological and physiological properties (Hess 1990, Tsien et al. 1991, Hofmann et al. 1994, Randall \& Tsien 1995). These $\mathrm{Ca}^{2+}$ channels have been reported to be composed of at least three subunits, $\alpha_{1}, \alpha_{2}-\delta$, and $\beta$ subunits (Zhang et al. 1993). The $\alpha_{1}$ subunit is a pore-forming component, functions as a voltage sensor, and is capable of generating $\mathrm{Ca}^{2+}$ channel activity in heterogeneous expression systems (Mikami et al. 1989). Molecular cloning studies have revealed that $\alpha_{1 \mathrm{~S}} / \alpha_{1 \mathrm{C}} / \alpha_{1 \mathrm{D}}, \quad \alpha_{1 \mathrm{~A}}, \quad \alpha_{1 \mathrm{~B}}$ and $\alpha_{1 \mathrm{E}}$ genes encode the $\alpha_{1}$ subunits of the dihydropyridine (DHP)sensitive L-type channels, $\omega$-agatoxin-IVA ( $\omega$-AgaIVA)-sensitive $\mathrm{P} / \mathrm{Q}$-type channels, $\omega$-conotoxinGVIA ( $\omega$-CgTx-GVIA)-sensitive N-type channels and DHP $/ \omega$-Aga-IVA $/ \omega-C g$ Tx-GVIA-insensitive R-type channels respectively (Mikami et al. 1989, Mori et al. 1991, Niidome et al. 1992, Williams et al. 1992). 
L-type, P/Q-type and N-type channels have been reported to play roles in $\mathrm{Ca}^{2+}$ influx-dependent insulin release (Stain et al. 1995, Ligon et al. 1998). The regulation of $\alpha_{1}$ subunit gene expression is clinically important, and elucidation of the mechanisms of expression of $\alpha_{1}$ subunit genes may facilitate understanding and treatment of $\beta$ cell disorders such as diabetes and hyperinsulinemia. However, although recent studies have reported the mechanisms of transcription of the $\alpha_{1 \mathrm{D}}, \alpha_{1 \mathrm{~A}}$ and $\alpha_{1 \mathrm{~B}}$ subunit genes in the neuronal cells (Kamp et al. 1995, Kim et al. 1997, Takahashi et al. 1999b), the mechanisms of transcription in the islet $\beta$ cells have not been determined.

Here, we describe the functional characterization of the $6.3 \mathrm{~kb} 5^{\prime}$-upstream promoter region of the $\mathrm{P} / \mathrm{Q}$-type $\mathrm{Ca}^{2+}$ channel $\alpha_{1 \mathrm{~A}}$ subunit gene in terms of its transcriptional control in the islet $\beta$ cells using transgenic mice and HIT-T15 insulinoma cells established by simian virus 40 transformation of Syrian hamster pancreatic $\beta$ cells (Santerre et al. 1981).

\section{MATERIALS AND METHODS}

\section{Isolation between mouse pancreatic acini and islets}

Isolation between pancreatic acini and islets was carried out using a modified collagenase digestion procedure (Gotoh et al. 1985). Briefly, Hanks' balanced salt solution (HBSS) containing $1.0 \mathrm{mg} / \mathrm{ml}$ collagenase (Sigma, St Louis, MO, USA) was injected into the pancreas through the duct. The distended pancreas was removed and digested in HBSS at $37^{\circ} \mathrm{C}$ for $10 \mathrm{~min}$. The digested pancreas was dispersed using a pipette. The dispersed tissues were divided between acini and islets by hand picking under a microscope or by centrifugation on a Ficoll (Amersham International plc, Amersham, Bucks, UK) gradient.

\section{Total RNA preparation and RT-PCR}

Total RNAs from HIT-T15 insulinoma (HIT) cells, mouse brain, pancreatic acini and islets were isolated with TRIzol Reagent (Gibco-BRL, Gaithersburg, MD, USA) according to the manufacturer's protocol. First strand cDNA was synthesized with $1 \mu \mathrm{g}$ total RNA using the SuperScript preamplification system (Gibco-BRL). Following first strand cDNA synthesis, PCR was carried out for 35 cycles of $94{ }^{\circ} \mathrm{C}$ for $1 \mathrm{~min}, 55^{\circ} \mathrm{C}$ for $1 \mathrm{~min}$ and $72^{\circ} \mathrm{C}$ for $2 \mathrm{~min}$, and a final extension of $72^{\circ} \mathrm{C}$ for $7 \mathrm{~min}$. The following primers were used to amplify the $\alpha_{1 \mathrm{~A}}$ subunit, amylase or insulin cDNA fragments: $\alpha_{1 \mathrm{~A}}-\mathrm{f}$
(5'-GAGATGATGGCCATT'TGGCCCAAC-3', sense, +5484 to +5508 , Genbank accession number, U76716) and $\alpha_{1 \mathrm{~A}}-\mathrm{r}$ (5'-TCAGAGATGGTACT GAGGTCA-3', antisense, +6041 to +6062$)$ for $\alpha_{1 \mathrm{~A}}$ subunit cDNA fragment; amylase-f (5'-AGTTCG TTCTGCTGCTTTCCCTC-3', sense, +852 to +874 , Genbank accession number, M16540) and amylase-r (5'-AGGTCTTGATGGGTTATGAA CTACA-3', antisense, +1368 to +1393 ) for amylase cDNA fragment; insulin-f (5'-CCTGCTCGT CCTCTGGGAGCC-3', sense, +4217 to +4237 , Genbank accession number, J00747) and insulin-r (5'-GCTGGTGCAGCACTGATCCACAAT-3', antisense, +4452 to +4465 ) for insulin cDNA fragment. The reaction product was subcloned into p'T7Blue(R)T-Vector (Novagen, Madison, WI, USA) and sequenced with a Dye Terminator Cycle Sequence kit (Applied Biosystems, Foster City, CA, USA) using U19 and T7 primers with an ABI Prism 377 DNA sequencer (Applied Biosystems). Computer analysis of potential transcription factor binding sites was carried out using GENETYX software (Soft Development, Tokyo, Japan).

\section{Plasmid constructions}

Plasmids for transient expression assay to identify transcriptional regulatory element(s) in the mouse $\alpha_{1 \mathrm{~A}}$ subunit gene were constructed by utilizing the placental alkaline phosphatase (PLAP) reporter gene. The plasmids $\mathrm{p}_{1 \mathrm{~A}} 6 \cdot 3$-PLAP, $\mathrm{p} \alpha_{1 \mathrm{~A}} 3 \cdot 0$-PLAP, pTK-PLAPI and $\mathrm{p} 6 \cdot 3-3 \cdot 0 \alpha_{1 \mathrm{~A}}$ thymidine kinase (TK)-PLAP were generated previously (Takahashi et al. 1999b). To construct $\mathrm{p} \alpha_{1 \mathrm{~A}} 1 \cdot 5-\mathrm{PLAP}, \mathrm{p} \alpha_{1 \mathrm{~A}} 3 \cdot 0-$ PLAP was digested with NotI and StuI, the NotI-StuI fragment was removed and the plasmid was religated. pBS104 (Takahashi et al. 1999b) was digested with EcoRV and StuI, and the EcoRVStuI fragment was inserted into the EcoRV site of pBluescript II KS - (Stratagene Inc., La Jolla, CA, USA) to yield $\mathrm{pBS} 3 \cdot 0-1 \cdot 5$. The plasmid $\mathrm{p} 3 \cdot 0-$ $1 \cdot 5 \alpha_{1 \mathrm{~A}}$ TK-PLAP was generated by inserting the SpeI-XhoI fragment of $\mathrm{pBS} 3 \cdot 0-1 \cdot 5$ into the SpeI-XhoI site of pTK-PLAPI. To construct pBS1 $5-0 \cdot 01, \mathrm{pBS} 104$ was digested with StuI and SmaI, and the StuI-SmaI fragment was inserted into the EcoRV site of pBluescript II $\mathrm{KS}-$. The plasmid $\mathrm{p} 1 \cdot 5-0 \cdot 01 \alpha_{1 \mathrm{~A}}$ TK-PLAP was generated by inserting the SpeI-XhoI fragment of pBS1.5-0.01 into the SpeI-XhoI site of pTK-PLAPI.

\section{Cell culture, transient transfection and PLAP assay}

HIT cells were maintained in glucose-free Dulbecco's modified Eagle's medium (DMEM) 
supplemented with $2 \mathrm{mM}$ sodium pyruvate, $1 \%$ non-essential amino acids, $55 \mathrm{nM} 2$-mercaptoethanol and 10\% fetal calf serum (FCS). NIH3T3 cells were grown in DMEM with $10 \%$ FCS. All culture media were supplemented with 100 units $/ \mathrm{ml}$ penicillin and $100 \mu \mathrm{g} / \mathrm{ml}$ streptomycin. To examine the expression of the mouse $\alpha_{1 \mathrm{~A}}$ subunit gene, we carried out transient expression assays using HIT and NIH3T3 cells. The cells were plated at a density of $1 \times 10^{5}$ cells in six-well dishes. Twentyfour hours after seeding, the cultures were washed extensively to remove non-adherent cells and the medium was replaced. On the second day, transfection was carried out with FuGENE 6 transfection reagent (Boehringer-Mannheim, Mannheim, Germany) according to the manufacturer's protocol. One microgram of the plasmid containing the mouse $\alpha_{1 \mathrm{~A}}$ subunit gene promoter region fused to the PLAP reporter gene and $1 \mu \mathrm{g}$ of the pSV- $\beta$ galactosidase control vector (Promega, Madison, WI, USA) were co-transfected into the cells. Twenty-four hours after transfection, the medium was replaced and culture was continued for an additional $24 \mathrm{~h}$. The culture supernatant was drawn from each sample and the PLAP activity was determined as described previously (Takahashi et al. 1999b). Data represent the means and standard deviations from three independent experiments, and statistical significance was evaluated by Student's $t$-test.

\section{Tissue preparation and lacZ staining in the pancreas of transgenic mice}

We generated transgenic mouse lines carrying fragments of $6 \cdot 3,3.0,1.5$ or $0.5 \mathrm{~kb}$ of the $5^{\prime}$-upstream region of the $\alpha_{1 \mathrm{~A}}$ subunit gene fused to the $E$. coli lac $Z$ reporter gene $\left(\alpha_{1 \mathrm{~A}} 6 \cdot 3-\right.$ lac $Z-14$, $\alpha_{1 \mathrm{~A}} 6 \cdot 3-$ lacZ-15, $\quad \alpha_{1 \mathrm{~A}} 3 \cdot 0-$ lacZ-10, $\quad \alpha_{1 \mathrm{~A}} 3 \cdot 0-$ lacZ-11, $\alpha_{1 \mathrm{~A}} 1 \cdot 5-$ lacZ-2, $\quad \alpha_{1 \mathrm{~A}} 1 \cdot 5-$ lacZ-4, $\alpha_{1 \mathrm{~A}} 0 \cdot 5-\mathrm{lac} Z-1$ and $\alpha_{1 \mathrm{~A}} 0 \cdot 5-\mathrm{lac} Z-7$ mice) as described elsewhere (Takahashi et al. 1999a). In the present study, the spatial expression pattern of the reporter gene in the pancreas was analyzed in these transgenic mouse lines. To detect expression of the lac $Z$ reporter gene in pancreas of transgenic mice, the 5 -bromo-4-chloro-3-indolyl- $\beta$-D-galactopyranoside (X-gal; Takara Shuzo, Kyoto, Japan) staining method was used (Takahashi et al. 1999a). Briefly, 10 -week-old transgenic mice were anesthetized with $10 \%$ nembutal (Abbot Laboratories, IL, USA), and perfused transcardially with fixing solution $(2 \%$ paraformaldehyde $/ 0.5 \%$ glutaraldehyde in $0.1 \mathrm{M}$ phosphate buffer, $\mathrm{pH}$ 7.4). The pancreas was removed, postfixed for an additional $30 \mathrm{~min}$, immersed in $30 \%$ sucrose for $12-24 \mathrm{~h}$, embedded in
OCT compound (Sakura Finetek, Tokyo, Japan) and sectioned with a cryostat at a thickness of $15 \mu \mathrm{m}$. Sections were incubated in staining solution $(0.5 \mathrm{mg} / \mathrm{ml} \mathrm{X}$-gal, $5 \mathrm{mM}$ potassium ferrocyanide, $5 \mathrm{mM}$ potassium ferricyanide and $1 \mathrm{mM} \mathrm{MgCl}_{2}$ in $0 \cdot 1 \mathrm{M}$ phosphate buffer, pH 7.4) overnight at $37^{\circ} \mathrm{C}$. After staining, the sections were rinsed with $0 \cdot 1 \mathrm{M}$ phosphate-buffered saline, counterstained with nuclear fast red (Vector, Burlingame, CA, USA), dehydrated and mounted on microscope slides using cedar wood oil (Sigma).

\section{RESULTS}

\section{P/Q-type $\mathrm{Ca}^{2+}$ channel $\alpha_{1 \mathrm{~A}}$ subunit mRNA expression in HIT cells and pancreas}

To examine the endogenous expression of the $\mathrm{P} / \mathrm{Q}$-type $\mathrm{Ca}^{2+}$ channel $\alpha_{1 \mathrm{~A}}$ subunit gene, RT-PCR analysis was performed for HIT cells, mouse pancreatic acini and islets. Isolation between acini and islets was confirmed by the expression of amylase or insulin (Fig. 1) and sequencing of these PCR products confirmed the amylase or insulin sequence (data not shown).

PCR of mRNA without reverse transcription was performed as a negative control. RT-PCR of mRNA from mouse brain was performed as a positive control. RT-PCR using primers specific for $\alpha_{1 \mathrm{~A}}$ subunit gene yielded an amplified product corresponding to the predicted size from HIT cells, islets and brain, but not from acini (Fig. 1). Sequencing of these PCR products confirmed the $\alpha_{1 \mathrm{~A}}$ cDNA sequence corresponding nucleotides of carboxyl terminus $(+5484$ to +6062$)$ (data not shown).

\section{Expression of PLAP reporter gene in HIT cells}

To address whether the $6.3 \mathrm{~kb}$ fragment of the $5^{\prime}$-upstream region of the mouse $\alpha_{1 \mathrm{~A}}$ subunit gene includes the regulatory sequences for expression in islet $\beta$ cells, we made transfection gene constructs, $\mathrm{p} \alpha_{1 \mathrm{~A}} 6 \cdot 3$-PLAP $(-6273$ to +269$), \mathrm{p \alpha}_{1 \mathrm{~A}} 3 \cdot 0$-PLAP $(-3021$ to +269$)$ and $\mathrm{p}_{1 \mathrm{~A}} 1 \cdot 5$-PLAP $(-1563$ to +269) (Fig. 2A). The promoterless construct basic-PLAP served as a background control and the pTK-PLAPI construct, which contains the TK promoter driving a PLAP reporter gene, as a positive control. We measured PLAP activity after transient transfection into HIT cells. As shown in Fig. 2B, $p \alpha_{1 \mathrm{~A}} 6 \cdot 3$-PLAP and $p \alpha_{1 \mathrm{~A}} 3 \cdot 0$-PLAP, but not $\mathrm{p} \alpha_{1 \mathrm{~A}} 1 \cdot 5$-PLAP, drove PLAP expression in HIT cells efficiently.

Fournal of Molecular Endocrinology (2000) 24, 225-232 

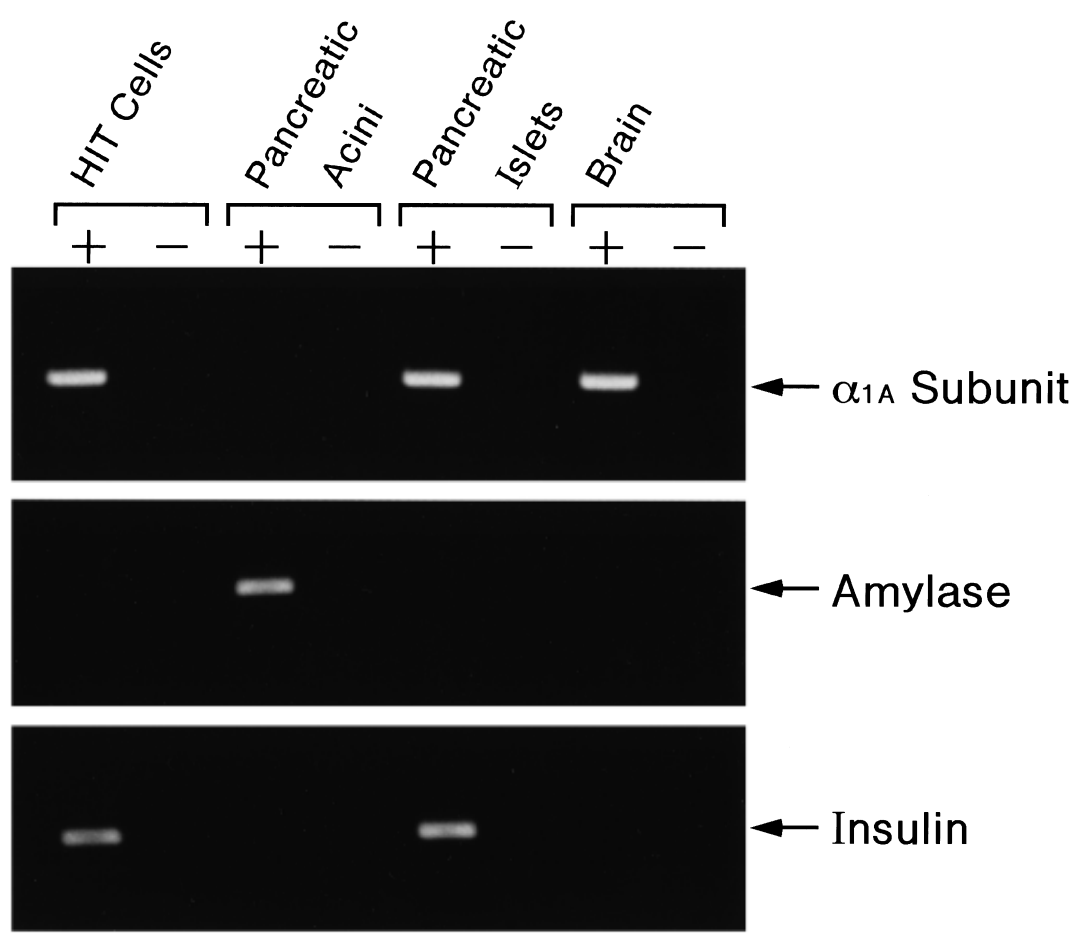

FIGURE 1. RT-PCR analysis of the endogenous P/Q-type $\mathrm{Ca}^{2+}$ channel $\alpha_{1 \mathrm{~A}}$ subunit gene in HIT cells, pancreatic acini and islets. Total RNAs were reverse-transcribed in the presence $(+)$ or in the absence $(-)$ of reverse-transcriptase and amplified by PCR using primers specific for $\alpha_{1 \mathrm{~A}}$ subunit, amylase or insulin gene. The PCR products were electrophoresed on a $1.5 \%$ agarose gel.

\section{Expression of lacZ reporter gene in the pancreas of transgenic mice}

The expression patterns of the transgenes in the pancreas of 10 -week-old transgenic mice were examined by histochemical staining. Incubation of pancreas sections from each transgenic mouse line with X-gal generated blue staining in the cells expressing the transgenes. Wild-type mice exhibited no positively stained cells in the pancreas. The expression patterns of the transgenic mouse lines are summarized in Table 1 . The levels and distributions of transgene expression were not correlated with the transgene copy number (data not shown). No differences were observed in the expression patterns of the transgenes between males and females in any of the transgenic mouse lines (data not shown).

Different expression patterns were observed among the $\alpha_{1 \mathrm{~A}} 6 \cdot 3-\mathrm{lac} Z(-6272$ to +498$), \alpha_{1 \mathrm{~A}} 3 \cdot 0$ lacZ $(-3021$ to +498$), \alpha_{1 \mathrm{~A}} 1 \cdot 5$-lac $Z(-1563$ to $+498)$ and $\alpha_{1 \mathrm{~A}} 0 \cdot 5-\mathrm{lac} Z(-497$ to +498$)$ mouse lines in pancreatic acini and islets. The $\alpha_{1 \mathrm{~A}} 1 \cdot 5$-lac $Z$ and $\alpha_{1 \mathrm{~A}} 0 \cdot 5$-lac $Z$ mouse lines failed to express $\beta$-galactosidase in the acini or islets. In contrast, the $\alpha_{1 \mathrm{~A}} 6 \cdot 3-\mathrm{lac} Z$ and the $\alpha_{1 \mathrm{~A}} 3 \cdot 0$-lac $Z$ mouse lines expressed the transgene in the islets, while the expression levels in the acini were relatively low (Fig. 3). Expression patterns of $\beta$-galactosidase were consistent among transgenic mouse lines carrying the same transgenes, suggesting that chromosomal effects could be excluded in these lines.

\section{Islet $\beta$ cell-specific enhancer element in the 5 -upstream region of the $\mathrm{P} / \mathrm{Q}$-type $\mathrm{Ca}^{2+}$ channel $\alpha_{1 \mathrm{~A}}$ subunit gene}

To examine whether the sequence between 3.0 and $1.5 \mathrm{~kb} 5^{\prime}$-upstream region $(-3021$ to -1563$)$ contributes to the islet $\beta$ cell expression, we made fusion gene constructs $\mathrm{p} 6 \cdot 3-3 \cdot 0 \alpha_{1 \mathrm{~A}}$ TKPLAP ( -6273 to -3021$)$, p $3 \cdot 0-1 \cdot 5 \alpha_{1 \mathrm{~A}}$ TK-PLAP $(-3021$ to -1563$)$ and $\mathrm{p} 1 \cdot 5-0 \cdot 01 \alpha_{1 \mathrm{~A}}$ TK-PLAP $(-1563$ to -11$)$ (Fig. 4A). PLAP activity was measured after transient transfection into HIT and NIH3T3 cells. The presence of the sequence between 3.0 and $1.5 \mathrm{~kb} 5^{\prime}$-upstream of the start 
(A)

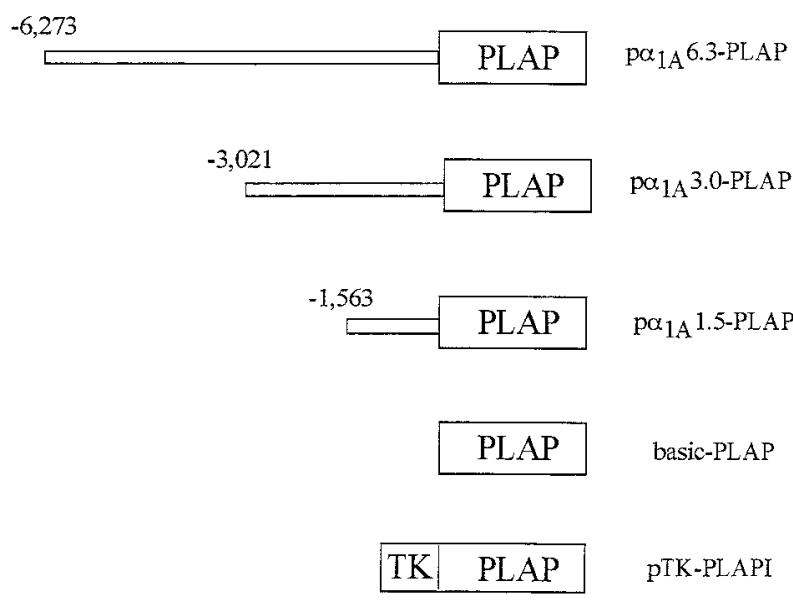

(B)

$p \alpha_{1 A} 6.3-P L A P$

$\mathrm{p} \alpha_{1 \mathrm{~A}} 3.0-\mathrm{PLAP}$

$\mathrm{pd}_{1 \mathrm{~A}} 1.5-\mathrm{PLAP}$

basic-PLAP

PTK-PLAPI

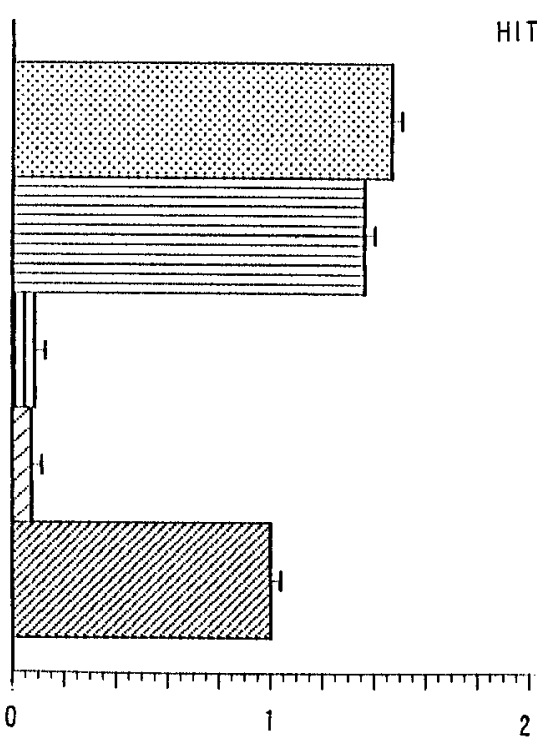

Relative PLAP activity

FIGURE 2. Promoter activity of the $5^{\prime}$-upstream region of the mouse P/Q-type $\mathrm{Ca}^{2+}$ channel $\alpha_{1 \mathrm{~A}}$ subunit gene. (A) Deletion constructs containing different lengths of the mouse $\alpha_{1 \mathrm{~A}}$ subunit gene promoter linked to the PLAP reporter gene were transiently transfected into HIT cells along with the pSV- $\beta$-galactosidase vector. (B) PLAP activity of different deletion constructs is shown relative to that of the vector pTK-PLAPI. All values are normalized to the $\mathrm{pSV}-\beta$-galactosidase vector. Results represent the mean relative activities \pm standard deviations of three independent experiments.

codon ( -3021 to -1563$)$, but not the sequences of between $6 \cdot 3$ and $3 \cdot 0 \mathrm{~kb}$ and between 1.5 and $0 \cdot 01 \mathrm{~kb}$ 5 -upstream, enhanced the activity of the TK promoter in HIT cells (Fig. 4B). In contrast, p6.3-
$3 \cdot 0 \alpha_{1 \mathrm{~A}}$ TK-PLAP, $\mathrm{p} 3 \cdot 0-1 \cdot 5 \alpha_{1 \mathrm{~A}}$ TK-PLAP and $\mathrm{p} 1 \cdot 5-$ $0 \cdot 01 \alpha_{1 \mathrm{~A}}$ TK-PLAP did not enhance the activity of the TK promoter in NIH3T3 cells (Fig. 4B).

\section{DISCUSSION}

The release of insulin from pancreatic islet $\beta$ cells and insulin-secreting cell lines is evoked by closing intracellular ATP-inhibited $\mathrm{K}_{\mathrm{ATP}}$ channels, depolarizing the cells (Longo et al. 1991, Larsson et al. 1996) and increases in $\mathrm{Ca}^{2+}$ influx through the DHP-sensitive L-type, $\omega$-Aga-IVA-sensitive $\mathrm{P} / \mathrm{Q}$-type and $\omega$-CgTx-GVIA-sensitive N-type voltage-activated $\mathrm{Ca}^{2+}$ channels (Stain et al. 1995, Ligon et al. 1998). The majority of insulin release is dependent on L-type $\mathrm{Ca}^{2+}$ channels and smaller portions are dependent on $\mathrm{P} / \mathrm{Q}$-type and $\mathrm{N}$-type (Stain et al. 1995, Ligon et al. 1998). As the relationships among the roles of these $\mathrm{Ca}^{2+}$ channels in insulin release are unclear, it is of interest to examine and compare the regulatory mechanisms underlying the $\beta$ cell-specific expression of $\alpha_{1}$ subunit genes. As a first step, we dissected the molecular mechanisms underlying the pancreatic islet $\beta$ cell expression of the mouse $\mathrm{P} / \mathrm{Q}$-type $\mathrm{Ca}^{2+}$ channel $\alpha_{1 \mathrm{~A}}$ subunit gene.

Transient transfection analysis in HIT cells indicated PLAP activity in $p \alpha_{1 \mathrm{~A}} 6 \cdot 3$-PLAP and $\mathrm{p} \alpha_{1 \mathrm{~A}} 3 \cdot 0$-PLAP, but not $\mathrm{p} \alpha_{1 \mathrm{~A}} 1 \cdot 5$-PLAP. This result showed that the sequence between 3.0 and $1.5 \mathrm{~kb}$ upstream of the start codon contains positive cis-regulatory elements that function in HIT cells.

The $\alpha_{1 \mathrm{~A}} 6 \cdot 3$-lac $Z$ and $\alpha_{1 \mathrm{~A}} 3 \cdot 0$-lac $Z$ mouse lines, but not $\alpha_{1 \mathrm{~A}} 1 \cdot 5$-lac $Z$ and $\alpha_{1 \mathrm{~A}} 0 \cdot 5$-lac $Z$, expressed lac $Z$ reporter gene in the pancreatic acini and islets. In situ hybridization and immunocytochemical studies have shown that the $\alpha_{1 \mathrm{~A}}$ subunit gene is expressed in the islets but not in the acini (Ligon et al. 1998). Our RT-PCR analysis also showed that the expression of $\alpha_{1 \mathrm{~A}}$ subunit gene is detected in the islets but not in the acini. Our results showed that in transgenic mouse lines the ectopic expression of the reporter gene was detected in the acini, suggesting that the $6.3 \mathrm{~kb} 5^{\prime}$-upstream region alone is not sufficient for the authentic expression of the $\alpha_{1 \mathrm{~A}}$ subunit gene. In the case of the tyrosine hydroxylase gene, authentic expression was not induced by the $5^{\prime}$-upstream region alone, however, the more exact expression was observed only after the insertion of additional $5^{\prime}$-upstream, intragenic, and $3^{\prime}$-downstream regions (Min et al. 1994). The blue staining in the acini in our transgenic mouse lines might have been due to the lack of a negative cis-regulatory element(s) in additional $5^{\prime}$-upstream, intragenic or $3^{\prime}$-downstream regions. The cells of 
TABLE 1. Expression of $\beta$-galactosidase activity in the pancreas of transgenic mice

\begin{tabular}{|c|c|c|c|c|c|c|c|c|c|}
\hline & \multicolumn{8}{|c|}{ Lines } & \multirow[b]{3}{*}{ Wild-type } \\
\hline & \multicolumn{2}{|c|}{$\alpha_{1 \mathrm{~A}} 0.5-\mathrm{lac} Z$} & \multicolumn{2}{|c|}{$\alpha_{1 \mathrm{~A}} 1.5-\mathrm{lac} Z$} & \multicolumn{2}{|c|}{$\alpha_{1 \mathrm{~A}} 3 \cdot 0-\mathrm{lac} Z$} & \multicolumn{2}{|c|}{$\alpha_{1 \mathrm{~A}} 6.3-\mathrm{lac} Z$} & \\
\hline & 1 & 7 & 2 & 4 & 10 & 11 & 14 & 15 & \\
\hline \multicolumn{10}{|l|}{ Pancreas } \\
\hline Acini & - & - & - & - & + & + & + & + & - \\
\hline Islets & - & - & - & - & ++ & ++ & ++ & ++ & - \\
\hline
\end{tabular}

Percentages of stained cells: $(+++)=>71 \%,(++)=50-70 \%,(+)=1-49 \%,(-)=$ no expression.

not less than half of the islets were stained with $\mathrm{X}$-gal. This demonstrated that the sequence between 3.0 and $1.5 \mathrm{~kb}$ upstream contains positive regulatory elements of expression in the $\beta$ cells, which comprise about $80 \%$ of islet cells. Thus, our results suggested that transcription of the $\alpha_{1 \mathrm{~A}}$ subunit gene might be under the same regulatory control in HIT cells in vitro and in the islet $\beta$ cells of transgenic mice in vivo.

To examine whether the sequence between $3 \cdot 0$ and $1.5 \mathrm{~kb}$ upstream contains a positive cisregulatory element for $\beta$ cell-specific expression, we carried out deletion analysis by in vitro transfection assay with HIT cells and non-insulinoma NIH3T3 cells. The p3.0-1.5 $\alpha_{1 \mathrm{~A}}$ TK-PLAP enhanced transcriptional activity of TK promoter, but not p6 $3-3 \cdot 0 \alpha_{1 \mathrm{~A}}$ TK-PLAP or $\mathrm{p} 1 \cdot 5-0 \cdot 01 \alpha_{1 \mathrm{~A}}$ TK-PLAP in HIT cells. We previously confirmed a lack of expression of the $\alpha_{1 \mathrm{~A}}$ subunit gene and no promoter activity of $\mathrm{pa}_{1 \mathrm{~A}} 6 \cdot 3-\mathrm{PLAP}$ in NIH3T3 cells (Takahashi et al. 1999b). In this study, we confirmed that the sequence between 6.3 and $3.0 \mathrm{~kb}$, between 3.0 and $1.5 \mathrm{~kb}$, and between 1.5 and $0 \cdot 01 \mathrm{~kb}$ upstream contains no positive cis-regulatory elements for $\beta$ cell-specific expression in NIH3T3 cells. These results showed that the positive cis-regulatory element for $\beta$ cell-specific expression is located in the sequence between 3.0 and $1.5 \mathrm{~kb}$ upstream of the mouse $\mathrm{P} / \mathrm{Q}$-type $\alpha_{1 \mathrm{~A}}$ subunit gene.

To understand the mechanisms responsible for expression of the $\alpha_{1 \mathrm{~A}}$ subunit gene in $\beta$ cells, an analogy can be drawn with the insulin and gastrin

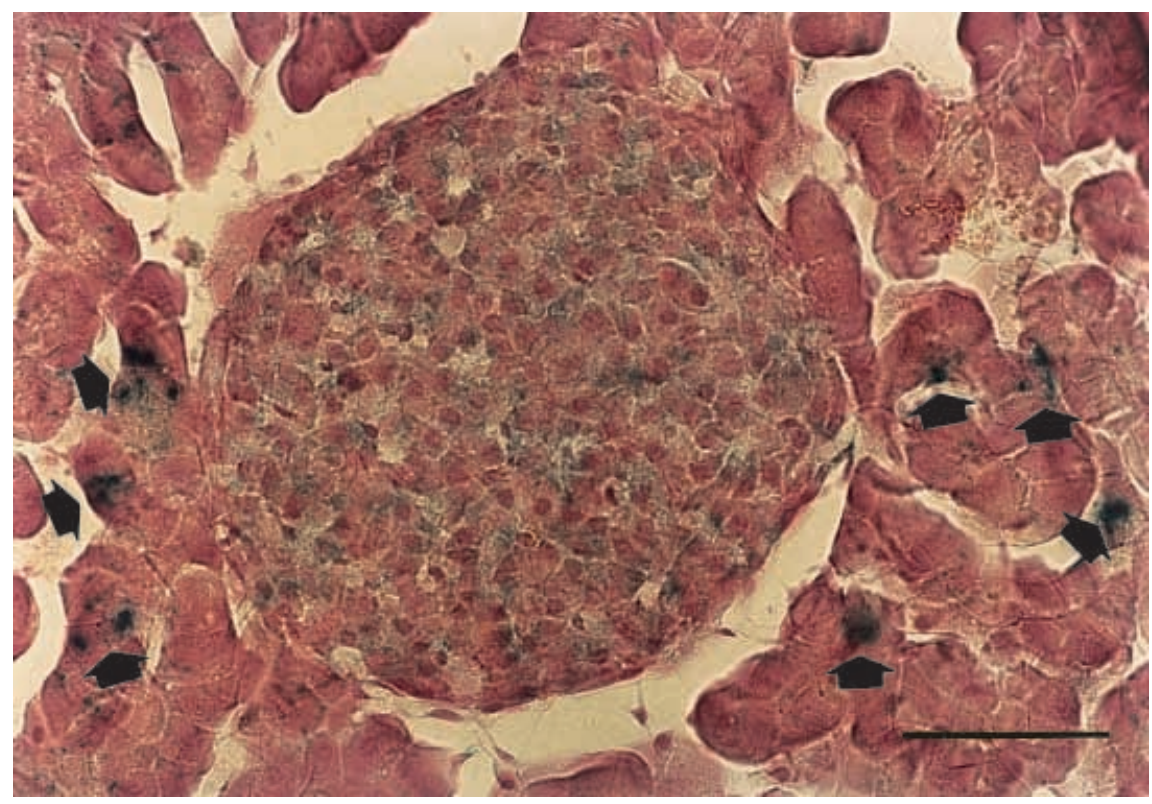

FIGURE 3. $\beta$-Galactosidase transgene expression patterns in the pancreas of $\alpha_{1 \mathrm{~A}} 6 \cdot 3$-lacZ-15. The section was counterstained with nuclear fast red. The transgene was expressed in the acinus and islets. Arrows indicate the transgene expression in the acinus. Bar $=400 \mu \mathrm{m}$. 
(A)

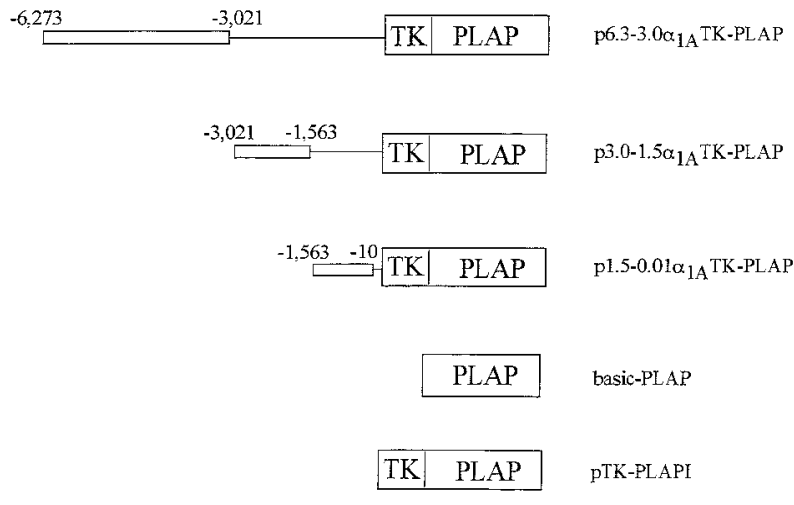

(B)

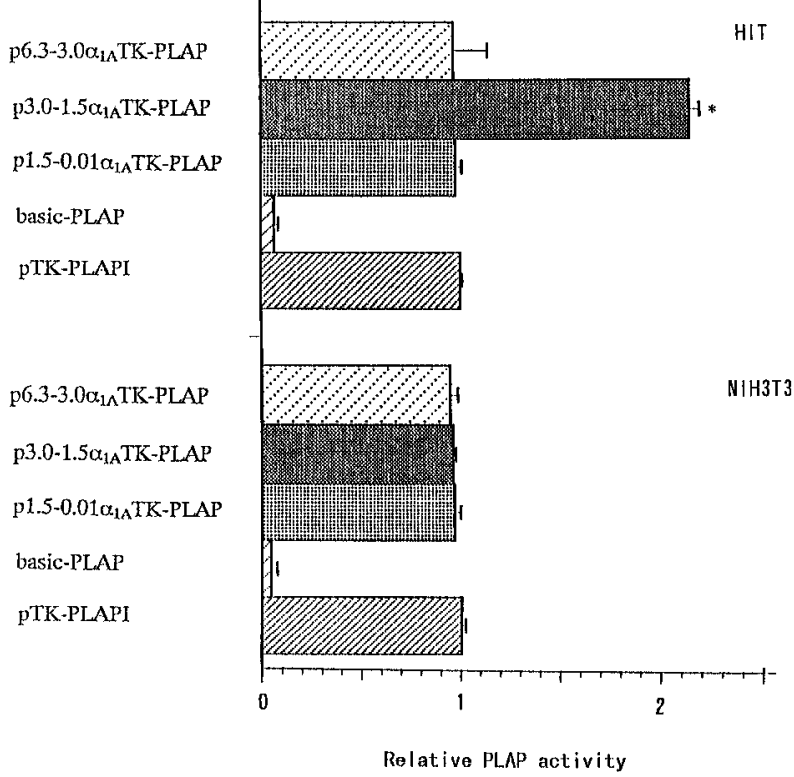

FIGURE 4. Fragment analysis of the cell-specific expression of the $\mathrm{P} / \mathrm{Q}$-type $\mathrm{Ca}^{2+}$ channel $\alpha_{1 \mathrm{~A}}$ subunit gene. (A) Deletion constructs containing different fragments upstream of the start codon inserted into the pTK-PLAPI vector were transiently transfected into HIT and NIH3T3 cells along with the pSV- $\beta$-galactosidase vector. (B) PLAP activities of different deletion constructs are expressed relative to the vector $\mathrm{p}$ TK-PLAPI. All values are normalized to the pSV- $\beta$-galactosidase vector. Results represent the mean relative activities \pm standard deviations of three independent experiments, and statistical significance was evaluated by Student's $t$-test $(* P<0 \cdot 005)$.

genes (Wang \& Brannd 1990, Moitoso de Vargas et al. 1997). When fused to the chloramphenicol acetyltransferase reporter gene, the $5^{\prime}$-upstream regions of the insulin and gastrin genes drove reporter gene expression in HIT cells. The sequence CATCTGG (Nir box) was demonstrated to be responsible for the $\beta$ cell-specific expression (Wang \& Brannd 1990, Moitoso de Vargas et al. 1997). Our computer-assisted analysis indicated that the distal upstream region $(-3021$ to -1563$)$ of the $\alpha_{1 \mathrm{~A}}$ subunit gene contains six putative Nir box-like sequences $(-2355$ CATCTTG - 2347; - 2325 CATATGG - 2319; - 2559 CATCTTG - 2353; - 2077 CATGTGG $-2071 ;-1979$ CATCTGC - 1973; and - 1866 CATGTGG -1800). It is likely that the Nir box-like sequence of the $\alpha_{1 \mathrm{~A}}$ subunit gene also contributes to specific expression of the $\alpha_{1 \mathrm{~A}}$ subunit gene in $\beta$ cells.

In our previous study, the brain cell type-specific expression mechanisms of the $\alpha_{1 \mathrm{~A}}$ subunit gene was examined (Takahashi et al. 1999a). The sequence between 3.0 and $1.5 \mathrm{~kb}$ upstream contained positive cis-regulatory elements for the expression in amygdaloid nucleus, septum, habenula medial nucleus, substantia nigra, inferior colliculus, pontine nucleus and cerebellar granule cells. In contrast, the sequence between 6.3 and $3.0 \mathrm{~kb}$ upstream contained negative $c i s$-regulatory elements for these neurons, except the inferior colliculus. Thus, the brain cell type-specific expression of the $\alpha_{1 \mathrm{~A}}$ subunit gene appeared to be controlled by the concerted action of positive and negative cisregulatory mechanisms, except the inferior colliculus. On the other hand, we detected no negative cis-regulatory elements for $\beta$ cell-specific expression in the $6.3 \mathrm{~kb} 5^{\prime}$-upstream region. The Nir box-like sequence has not been reported to be responsible for specific expression of brain cells, including the inferior colliculus cells. It is likely that the expression mechanisms of the $\alpha_{1 \mathrm{~A}}$ subunit gene are different between $\beta$ cells and brain cells.

The density of $\omega$-Aga-IVA-sensitive current in $\beta$ cells varies considerably from cell to cell (Ligon et al. 1998). This heterogeneity likely reflects variations in $\alpha_{1 \mathrm{~A}}$ subunit gene expression levels. As between $50 \%$ and $70 \%$ of the cells in the islets showed blue staining, our $\alpha_{1 \mathrm{~A}} 6 \cdot 3-\mathrm{lac} Z$ and $\alpha_{1 \mathrm{~A}} 3 \cdot 0$ lac $Z$ transgenic mouse lines did not express detectable levels of the lac $Z$ reporter gene in all $\beta$ cells. Thus, it is likely that negative cis-regulatory elements might be active in $\beta$ cells that were not stained with $\mathrm{X}$-gal. Cell-specific regulation of transcription of the $\alpha_{1 \mathrm{~A}}$ subunit gene may be one of the mechanisms responsible for the diversity in the pharmacological properties of $\beta$ cells. This phenomenon should be examined in future studies.

In summary, we have identified a region in the $5^{\prime}$-upstream region of the mouse $\mathrm{P} / \mathrm{Q}$-type $\alpha_{1 \mathrm{~A}}$ subunit gene $(-3021$ to -1563$)$ that contains a positive cis-acting regulatory element likely to be 
responsible for the pancreatic islet $\beta$ cell expression of the $\alpha_{1 \mathrm{~A}}$ subunit gene. On the other hand, the ectopic expression of reporter gene in acini has showed that the $6 \cdot 3 \mathrm{~kb}$ of the $5^{\prime}$-upstream region alone might be a lack of a negative cis-regulatory element(s) to suppress $\alpha_{1 \mathrm{~A}}$ subunit gene expression in acini. Further studies, including deletion and additional sequence analysis and identification of trans-regulatory factors, should help to clarify the mechanism of $\beta$ cell-specific expression of the $\mathrm{P} / \mathrm{Q}$-type $\alpha_{1 \mathrm{~A}}$ subunit gene.

\section{ACKNOWLEDGEMENTS}

We thank Dr M Okada for providing the HIT-T15 cells. We also thank Mr K Oyama for technical support.

\section{REFERENCES}

Ashcroft FM, Harrison DE \& Ashcroft SJH 1984 Glucose induces closure of single potassium channels in isolated rat pancreatic beta-cells. Nature 312 446-448.

Boyd AE 1992 The role of ion channels in insulin secretion. Fournal of Cell Biochemistry 48 234-241.

Curry DL, Bennett LL \& Grodsky GM 1968 Requirement for calcium ion in insulin secretion by the perfused rat pancreas. American Fournal of Physiology 214 174-178.

Devis G, Somers G, Van Obberghen E \& Malaisse WJ 1975 Calcium antagonists and islet function. I. Inhibition of insulin release by verapamil. Diabetes 24 247-251.

Gotoh M, Maki T, Kiyouzumi T \& Satomi S 1985 An improved method for isolation of mouse pancreatic islets. Transplantation 40 437-438.

Hales CN \& Milner RDG 1968 Cations and the secretion of insulin from rabbit pancreas in vitro. Fournal of Physiology 199 177-187.

Hess P 1990 Calcium channels in vertebrate cells. Annual Review of Neuroscience 13 337-356.

Hofmann F, Biel M \& Flockerzi V 1994 Molecular basis for $\mathrm{Ca}^{2+}$ channel diversity. Annual Review of Neuroscience 17 399-418.

Kamp TJ, Mitas M, Fields KL, Asoh S, Chin H, Marban E \& Nirenberg M 1995 Transcriptional regulation of the neuronal L-type calcium channel $\mathrm{a}_{1 \mathrm{D}}$ subunit gene. Cellular and Molecular Neurobiology 15 307-326.

Kim DS, Jung HH, Park SH \& Chin H 1997 Isolation and characterization of the $5^{\prime}$-upstream region of the human $\mathrm{N}$-type calcium channel $\alpha_{1 \mathrm{~B}}$ subunit gene. Fournal of Biochemical Chemistry 272 5098-5104.

Larsson O, Kindmark H, Branstrom R, Fredholm B \& Berggrem PO 1996 Oscillations in $\mathrm{K}_{\mathrm{ATP}}$ channel activity promote oscillations in cytoplasmic free $\mathrm{Ca}^{2+}$ concentration in the pancreatic beta cell. Proceedings of the National Academy of Sciences of the USA 93 5161-5165.

Ligon B, Boyd AE III \& Dunlap K 1998 Class A calcium channel variants in pancreatic islets and their role in insulin secretion. Fournal of Biochemical Chemistry 273 13905-13911.

Longo E, Tornheim K, Deeney JT, Varnum BA, Tillotson D, Prentki M \& Corkey BE 1991 Oscillations in cytosolic free $\mathrm{Ca}^{2+}$, oxygen consumption, and insulin secretion in glucose-stimulated rat pancreatic islets. Fournal of Biochemical Chemistry 266 9314-9319.
Mikami A, Imoto K, Tanabe T, Niidome T, Mori Y, Takeshima H, Narumiya S \& Numa S 1989 Primary structure and functional expression of the cardiac dihydropyridinesensitive calcium channel. Nature 340 230-233.

Min N, Joh TH, Kim KS, Peng C \& Son JH 1994 5' Upstream DNA sequence of the rat tyrosine hydroxylase gene directs high-level and tissue-specific expression to catecholaminergic neuron in the central nervous system of transgenic mice. Molecular Brain Research 27 281-289.

Moitoso de Vargas L, Sobolewski J, Siegel R \& Moss LG 1997 Individual beta cells within the intact islet differentially respond to glucose. Fournal of Biochemical Chemistry 272 26573-26577.

Mori Y, Friedrich T, Kim MS, Mikami A, Nakai J, Ruth P, Bosse E, Hofmann F, Flockerzi V, Furuichi T, Mikoshiba K, Imoto K, Tanabe T \& Numa S 1991 Primary structure and functional expression from complementary DNA of a brain calcium channel. Nature 350 398-402.

Newgard CB \& McGarry JD 1995 Metabolic coupling factors in pancreatic beta-cell signal transduction. Annual Review of Biochemistry 64 689-719.

Niidome T, Kim MS, Friedrich T \& Mori Y 1992 Molecular cloning and characterization of a novel calcium channel from rabbit brain. FEBS Letters 308 7-13.

Randall A \& Tsien RW 1995 Pharmacological dissection of multiple types of $\mathrm{Ca}^{2+}$ channel currents in rat cerebellar granule neurons. Fournal of Neuroscience 15 2995-3012.

Santerre RF, Cook RA, Crisel RMD, Sharp JD, Schmidt RJ, Williams DC \& Wilson CP 1981 Insulin synthesis in a clonal cell line of simian virus 40 -transformed hamster pancreatic beta cells. Proceedings of the National Academy of Sciences of the USA 78 4339-4343.

Stain LS, Tavalin SJ, Kinard TA \& Teague J 1995 Contribution of L- and non-L-type calcium channels to voltage-gated calcium current and glucose-dependent insulin secretion in HIT-T cells. Endocrinology 136 4589-4601.

Takahashi E, Miyamoto N, Oki T, Kajiwara N, Furuya K, Taniguchi K, Yagami K, Niidome T, Tanaka I \& Katayama K $1999 a$ Neuron-specific expression of reporter gene in transgenic mice carrying the $5^{\prime}$-upstream region of mouse $\mathrm{P} / \mathrm{Q}$-type $\mathrm{Ca}^{2+}$ channel $\alpha_{1 \mathrm{~A}}$ subunit gene fused to $E$. coli lacZ reporter gene. Brain Research 850 47-54.

Takahashi E, Murata Y, Oki T, Miyamoto N, Mori Y, Takada N, Wanifuchi H, Wanifuchi N, Yagami K, Niidome T, Tanaka I \& Katayama K $1999 b$ Isolation and functional characterization of the $5^{\prime}$-upstream region of mouse P/Q-type $\mathrm{Ca}^{2+}$ channel $\alpha_{1 \mathrm{~A}}$ subunit gene. Biochemical and Biophysical Research Communications 260 54-59.

Tsien RW, Ellinor PT \& Horne WA 1991 Molecular diversity of voltage-dependent $\mathrm{Ca}^{2+}$ channels. Trends in Pharmacological Science 12 349-354.

Wang TC \& Brannd SJ 1990 Islet cell-specific regulatory domain in the gastrin promoter contains adjacent positive and negative DNA elements. Fournal of Biochemical Chemistry 265 8909-8914.

Williams ME, Brust PF, Feldman DH, Patthi S, Simerson S, Maroufi A, McCue AF, Veliçelebi G, Ellis SB \& Harpold MM 1992 Structure and functional expression of an $\omega$-conotoxin-sensitive human $\mathrm{N}$-type calcium channel. Science 257 389-395.

Zhang JF, Randall AD, Ellinor PT, Horne WA, Sather WA, Tanabe T, Schwarz TL \& Tsien RW 1993 Distinctive pharmacology and kinetics of cloned neuronal $\mathrm{Ca}^{2+}$ channels and their possible counterparts in mammalian CNS neurons. Neuropharmacology 32 1075-1088.

RECEIVED 25 October 1999 